\title{
Ten years polio-free: anniversary in the World Health Organization European Region
}

Eurosurveillance editorial team (eurosurveillance@ecdc.europa.eu) ${ }^{1}$

1. European Centre for Disease Prevention and Control (ECDC), Stockholm, Sweden

Citation style for this article:

Eurosurveillance editorial team. Ten years polio-free: anniversary in the World Health Organization European Region . Euro Surveill. $2012 ; 17(17)$ :pii=20157.

Available online: http://www.eurosurveillance.org/ViewArticle.aspx?Articleld=20157

In 2002, the World Health Organization (WHO) European Region was declared polio-free [1]. This week, 21-27 April 2012, the seventh European Immunization Week highlights the ten-year anniversary of the polio-free status [2]. In spite of a large outbreak of imported wild poliovirus in Tajikistan in 2010, the Region has retained its polio-free status, as confirmed by the European Regional Certification Commission for Poliomyelitis Eradication in August 2011 [3].

It was on 23 April 2010 that the WHO announced the confirmation of wild poliovirus serotype 1 (WPV 1 ) in seven samples obtained from children with acute flaccid paralysis (AFP) in Tajikistan. Genetic sequencing determined that the poliovirus was most closely related to virus from Uttar Pradesh, India. In total 136 (80\%) of the AFP cases were in children aged under five years (age range 0-17 years). Cases were mainly reported from districts bordering Afghanistan and Uzbekistan [4].

While remaining polio-free is an achievement to celebrate and a good example of how immunisation can control the spread of disease, the 2010 outbreak was a poignant reminder of the need to stay vigilant. Due to ongoing threats in countries bordering or nearby the European region such as China and Pakistan, polio continues to be a threat [5].

\section{References}

1. Certification of Poliomyelitis Eradication: European Region declared 'polio-free'. Fifteenth meeting of the European Regional Certification Commission. Copenhagen, 19-21 June 2002, p 103. Available from: http://www.euro.who.int/ document/E88105.pdf

2. World Health Organization Regional Office for Europe. Core Communications Package. European Immunization Week 21-27 April 2012. Available from: http://www.euro.who.int/_data/ assets/pdf_file/o020/160751/EIW-2012-Core-CommunicationsPackage.pdf

3. World Health Organization Regional Office for Europe. Polio kicked out of Europe: European Region to retain polio-free status, but constant vigilance is needed. Press release. Copenhagen 25 August 2011. WHO. Available from: http://www. euro.who.int/en/what-we-publish/information-for-the-media/ sections/latest-press-releases/polio-kicked-out-of-europeeuropean-region-to-retain-polio-free-status,-but-constantvigilance-is-needed

4. World Health Organization Country Office Tajikistan, WHO Regional Office for Europe, European Centre for Disease Prevention and Control. Outbreak of poliomyelitis in Tajikistan in 2010: risk for importation and impact on polio surveillance in Europe? Euro Surveill. 2010;15(17):pii=19558. Available from: http://www.eurosurveillance.org/ViewArticle. aspx?Articleld $=19558$

5. European Centre for Disease Prevention and Control. Annual Epidemiological Report on Communicable Diseases in Europe 2010. Stockholm: ECDC; 2010. Available from: http://ecdc. europa.eu/en/publications/publications/1011_sur_annual_ epidemiological_report_on_communicable_diseases_in_ europe.pdf 